\author{
KATARZYNA Mirgos (iD \\ Uniwersytet Gdański
}

\title{
A pomidory są te, co zawsze. Refleksje z baskijskiego terenu ${ }^{1}$
}

Prawie wszyscy w swoim życiu podróżowali, czy nawet mieszkali za granica. Niektórzy rzucaja się w wir otaczającej ich rzeczywistości $z$ wyjątkowa pasją. Tak właśnie rodzi się antropolog.

B. Malinowski ${ }^{2}$

$S^{t}$ tudiując etnologię, trafiłam na wykładowców, którzy z pasją opowiadali o terenach swoich badań, którzy, nie bacząc na trudności czy niewygody, wciąż wracali do swych rozmówców. Pamiętam jeszcze zachwyt, z jakim słuchałam o ich doświadczeniach, i uczucie, jakby wraz z ich opowieściami otwierały się przede mną inne światy, co bez wątpienia wpłynęło na to, czym dla mnie jest antropologia i jakie znaczenie mają dla mnie badania terenowe. Sama "swój” teren znalazłam dość szybko, bo jeszcze podczas studiów licencjackich, gdy moje zainteresowanie nauką języka baskijskiego przerodziło się w wielką fascynację tym niewielkim regionem Europy. W tamtym czasie był on kojarzony głównie $\mathrm{z}$ terrorem sianym przez ETA, choć w moim macierzystym ośrodku $\mathrm{u}^{3}$ pamiętano nadal o badaniach prowadzonych wśród Basków przez profesora Eugeniusza Frankowskiego. Kraj Basków stał się dla mnie miejscem ważnym, a z niektórymi z moich rozmówców spotykam się i pracuję od kilkunastu lat.

\footnotetext{
${ }_{1}^{1}$ Tekst powstał w ramach realizacji projektu Narodowego Centrum Nauki pod tytułem „Nowa rodzina baskijska? Tradycja, polityka kulturowa i nowe formy życia rodzinnego" (numer projektu: 2016/21/B/HS3/00045).

2 Cytat za: Young 2008: 35.

${ }^{3}$ Instytut Etnologii i Antropologii Kulturowej Uniwersytetu im. A. Mickiewicza w Poznaniu.
} 
A wszystko zaczęło się od przypadku. Koleżanka powiedziała mi o lektoracie języka baskijskiego i tak, zaintrygowana, trafiłam na pierwsze zajęcia. Euskara, czyli język baskijski, zachwycił mnie natychmiast. Nie opuściłam żadnej lekcji i wkrótce zaczęłam marzyć o tym, by na własne oczy zobaczyć ten region i tamtejszych ludzi. W pierwszą podróż do Baskonii wyruszyłam autostopem z przyjacielem ze studiów. To była wyprawa pełna przygód, ale do celu dotarliśmy. Od samego początku, już podczas pierwszych badań, starałam się mówić po baskijsku, choć nie było to łatwe. Umawiając się przez telefon na wywiad z jednym z bertsolari - śpiewaków improwizatorów, zapomniałam na przykład jak brzmią w euskara wszystkie nazwy dni tygodnia poza piątkiem (ostirala) i choć mój rozmówca proponował inne terminy (jak widać ten akurat dzień nie był dla niego odpowiedni), ja wciąż prosiłam o ten jeden jedyny zapamiętany dzień. W końcu, wyczuwając moją desperację, zgodził się na piątkową rozmowę. W ubiegłym roku wróciłam do miejscowości, w której się wówczas spotkaliśmy, po raz pierwszy od tamtych badań ${ }^{4}$ i przez chwilę miałam uczucie, jakbym sama spotkała siebie z przeszłości.

Niniejszy tekst również stanowić będzie swoistą retrospektywę oraz refleksję nad codziennością moich terenowych badań. Takie opowieści, choć w coraz większym stopniu obecne i doceniane w relacjach badawczych, bywają też krytykowane jako nienaukowe czy narcystyczne (Kacperczyk 2014: 64-65). Jednocześnie, wbrew pozorom, szeroko rozumiane autoetnografia i refleksyjność niosą ze sobą spore trudności i wymagają odwagi, ze względu na fakt dzielenia się z czytelnikiem intymnymi refleksjami i doświadczeniami. W takim wypadku, jak zauważa Carolyn Ellis, krytyce poddana może być nie tylko praca autora/-ki, ale i jego/ jej życie (Ellis 2004: 19).

\section{Zmysłowy Kraj Basków}

Wszędzie rozpoznałabym zapach baskijskiego powietrza; i tamtejszy pejzaż, z jego pokrytymi zielenią górami, wiejskimi domami, stadami owiec, charakterystycznym liternictwem ${ }^{5}$. Jadąc na badania, niekiedy wracam do tych samych miejscowości (w których nawet sprzedawcy w sklepach mówią do mnie: „Witamy ponownie"), czasem zaś zamieszkuję w zupełnie nowych. Staram się podążać za ludźmi, wydarzeniami, przedmiotami. W trakcie ostatnich kilkuletnich badań przez okna moich "terenowych” mieszkań widziałam rozmaite pejzaże. W Tolosie patrzyłam na przepływającą przez miasteczko rzekę, pobliskie góry, a na nich pojedyncze baserriak - tradycyjne gospodarstwa. Co sobotę mogłam obserwować ludzi zmierzających na tutejszy targ. W Orio spoglądałam na meczet,

\footnotetext{
${ }^{4}$ To znaczy od $2001 \mathrm{r}$.

${ }^{5}$ W Kraju Basków stosowany jest specyficzny styl zapisu liter, powszechnie wykorzystywany na przykład na szyldach sklepów czy barów, ale też choćby w nazwach ulic, i uznawany przez niektórych za element "baskijskości”. Stanowi on charakterystyczny składnik miejscowego pejzażu.
} 
a bliskość innych mieszkań czyniła mnie niezamierzenie obserwatorką codziennych czynności mych sąsiadów. W Zarautz przyglądałam się wypasanym na zielonych wzgórzach owcom, a w weekendy liczyłam przejeżdżających szosą kolarzy. W Vitorii-Gasteiz miałam widok na Gaztetxe ${ }^{6}$. W Sopeli patrzyłam na zachodzące ponad górami i domami słońce, a zza płotu przyglądał mi się kudłaty pies. Jednak różnice związane z tymi miejscami nie ograniczały się tylko do różnorodnych pejzaży. Odmienność pomiędzy regionami, a zwłaszcza językowym charakterem każdego z miejsc, sprawiała, iż czasem miałam wrażenie, że przebywam w zupełnie różnych krajach. Prowadzę badania w rozmaitych środowiskach zamieszkujących region baskijski - spotykam się z Polakami, imigrantami, baskijskojęzycznymi lub hiszpańskojęzycznymi mieszkańcami Baskonii. Kultura baskijska to dla mnie raczej kultury baskijskie (jedną z nich jest kultura baskijskojęzyczna). Nie bez znaczenia są różnice światopoglądowe, wiek, indywidualne doświadczenia moich rozmówców. Moje relacje z każdą z tych grup są inne, czasem mam też poczucie, że ich wzajemne stosunki i wiedza o sobie nawzajem są dość ograniczone, i że gdybym spotkała się jednocześnie z kilkorgiem z nich, niełatwo byłoby im się porozumieć. Różnice dostrzegalne są też na poziomie kontaktu cielesnego. W Kraju Basków, podobnie jak w całej Hiszpanii, z powitaniem lub przedstawieniem kogoś wiążą się dwa pocałunki w policzki. W porównaniu z Polską kontakty fizyczne są w moim odczuciu mniej sformalizowane i bliższe. Mimo to Baskowie słyną z większej powściągliwości w okazywaniu sobie uczuć niż mieszkańcy innych hiszpańskich regionów. Katalonka mieszkająca w Baskonii mówiła mi o odmiennych, bliższych fizycznych kontaktach zachodzących pomiędzy grupkami przyjaciół, którzy serdecznie przytulają się na powitanie, a spacerując ulicami, nierzadko się obejmują. Podkreślała ona, jak trudno było jej samej przyzwyczaić się do większego dystansu między ludźmi w regionie baskijskim. Ja również doświadczyłam wielu różnic w podejściu do cielesności wśród moich rozmówców zamieszkujących region baskijski. Ponadto warto zauważyć, że uczestnictwo w tamtejszych „praktykach cielesnych” wpłynęło też na to, jak sama zaczęłam odczuwać i postrzegać własne ciało (ciało badacza/antropologa to według mnie również istotne narzędzie poznania).

Moją codzienność w Kraju Basków wypełniają też dźwięki inne niż w Polsce. Zazwyczaj jest głośniej, bo i sami Baskowie zauważają swoją hałaśliwość. W Orio wczesnym rankiem budzi mnie dziecko sąsiadów, z niezwykłym upodobaniem do "gry" na instrumentach. W Vitorii-Gasteiz koncerty organizowane przez kilka dni w tygodniu naprzeciwko mojego domu dają mi poczucie, że mimo szczelnie zasłoniętych rolet, znajduję się tuż pod sceną. Gwar w autobusie z Zarautz do Getarii sprawia, że nie jestem w stanie dokończyć telefonicznej rozmowy, w porze obiadu w restauracji w Donostii dyskusje przy stolikach stają

${ }_{6}^{6}$ Literalnie - „Dom młodych". Jest to budynek zajęty przez grupy młodzieżowe, będący często miejscem imprez o charakterze kulturalnym czy warsztatów, a także centrum spotkań czy aktywizacji lokalnej społeczności. Podczas manifestacji w obronie jednego z działaczy gaztetxe (Maravillas) w 2018 r. pojawiło się hasło: Ez da gaztetxe bat, mundua ulertzeko modu bat baizik („To nie jest tylko gaztetxe, to sposób rozumienia świata”). 
się z minuty na minutę donośniejsze. Mój towarzysz śmieje się, że to typowe, a moja współlokatorka wspomina, że po operacji ucha musiała wyjść z restauracji, bo rosnący gwar sprawiał jej fizyczny ból. Baskijska powściągliwość, będąca przedmiotem licznych żartów, znika jak widać przy stole (w myśl powiedzenia, że jeśli chcesz zaprzyjaźnić się z Baskiem, zaproś go na smaczny posiłek (Etxeberria 2012: 18). Ale i ja delektuję się tutejszymi smakami, zielonymi smażonymi papryczkami (mówi się, że te najlepsze pochodzą z Gerniki), słodyczą mojego ulubionego budyniowego ciasta, intensywnością owczego sera. Wujek mojego przyjaciela jest pasterzem, który od lat wytwarza sery. Dziś martwi się o to, że nie ma komu przekazać swojej wiedzy i umiejętności: „Powiedz mi, jeśli znasz kogoś, kto chce się nauczyć" - mówi. Poza tym tu, tak jak miejscowi, piję znacznie więcej kawy, a o herbacie zapominam. Stałym elementem mojej diety jest oliwa i chleb spożywany do wszystkiego (miejscowi z chlebem jadają nawet frytki). Dzięki imigrantom poznaję smaki Maroka czy Meksyku. Często chodzę w góry, uczestnicząc w tej „ulubionej” i „prawdziwie baskijskiej” aktywności (Strubell 2005: 27-28). Mam moje ulubione trasy, a w każdej miejscowości zakątki, do których wracam. Są to miejsca znaczące, które składają się na moją mentalną mapę Baskonii. Wiem, kiedy w danym miejscu organizuje się jarmark staroci, a kiedy targowisko, na którym okoliczni gospodarze sprzedają swoje produkty. Po kilku dniach po przyjeździe „w teren” śnię po baskijsku.

Staram się doświadczać terenu wielozmysłowo, uważam, że „bycie z ludźmi to nie tylko spotkanie face to face, to dzielenie z nimi zapachów, dźwięków, faktur materiałów i kształtów przedmiotów" (Majbroda 2013: 23). Jednocześnie dostrzegam, że moi rozmówcy żyją w nieco innych "rzeczywistościach zmysłowych" (Hall 2009: 13). Jedna z młodych kobiet opisywała mi zapach, który kojarzy jej się z dziećmi i był to zapach tutejszej wody kolońskiej, którą miejscowi z upodobaniem, a czasem bez umiaru, wylewają na ciała swych pociech: „kiedy czuję ten zapach to od razu myślę - „dziecko” - podkreśliła.

Zbigniew Benedyktowicz, wskazując na wartość pochylenia się nad literaturą, teatrem czy filmem, które jednak bywa często krytykowane jako „pięknoduchostwo” czy „esejowatość”, zauważył, że „wizja sterylnego naukowo etnografa, który nie czyta literatury, nie słucha muzyki, nie chodzi do kina, pochylony nad swoją robótką, nadal pozostaje pokusą" (Benedyktowicz 2016: 14-15). Odnoszę jego słowa do sposobu bycia w terenie. Ważne jest dla mnie to, aby doświadczać tamtejszej codzienności na wielu polach. Dlatego sięgam po baskijską literaturę, film, sztukę, muzykę, prasę. W tych wytworach tutejszej kultury widzę cenne źródło informacji o tym, co dla miejscowych istotne. Uważam, że z baskijskiej poezji albo filmu, który do kin po raz pierwszy przyciągnął starszych ludzi, niekiedy na pierwszy seans w ich życiu, wiele dowiedzieć się można o tutejszej kulturze. 


\section{Mówienie po baskijsku czyni nas Baskami ${ }^{7}$}

Mój rozmówca stoi przy zlewie i myje naczynia. Kieruje do mnie kilka słów i słyszę, że mówi w swoim dialekcie, choć dotąd rozmawialiśmy w zestandaryzowanym baskijskim (euskara batua). Kiedy zwracam mu na to uwagę, dziwi się; nie zauważył tego, a ja już wiem, że czuje się ze mną swobodnie. Język baskijski, jego znaczenie, językowe relacje, w szczególny sposób mnie interesują podczas badań w Baskonii. Gdziekolwiek jestem, wsłuchuję się w rozmowy, użyte słowa, z upodobaniem śledzę lokalne odmienności, zachwycają mnie baskijskie formy gramatyczne, wreszcie to, co wyjątkowo dla mnie intrygujące - sposób wyboru języka komunikacji. Dla mnie zmiana językowego kodu to często wysiłek, dla miejscowych - coś naturalnego, choć ich dwujęzyczność, mimo że spontaniczna i swobodna, ma pewne ograniczenia. Jeden z euskaldun zaharrak ${ }^{8}$ powiedział mi, że nie rozumie poezji w języku hiszpańskim, inny, że uczestnictwo w terapeutycznej grupie wsparcia w języku hiszpańskim jest dla niego trudne, bo nie potrafi o swoich uczuciach wypowiadać się w tym języku. Niektórzy mówią o językowych kalkach czy błędach, które notorycznie popełniają: „Często mylę rodzaje” - zauważa jeden z moich rozmówców. - „Pytam na przykład: widziałaś tę dom? Choć powinienem powiedzieć: ten dom9. To dlatego, że w języku baskijskim ich nie ma".

Balentin Berrio-Otxoa, dziewiętnastowieczny duchowny, w liście do matki pisał, że "gdy spotkają się w niebie, będą musieli rozmawiać po hiszpańsku, bo euskara jest już prawie zapomniana" (za: Zuazo 2010: 32). Tymczasem dziś w języku baskijskim powstaje bogata literatura, jest on obecny w edukacji i w coraz większym stopniu na baskijskich ulicach. W Tolosie słyszę któregoś dnia starszą kobietę, która rozmawia z przyjaciółką po baskijsku i myślę, jak zmienił się Kraj Basków w ostatnich latach. Niektórzy z moich rozmówców wspominają jeszcze czasy, gdy mówienie w euskara było synonimem braku wykształcenia i powodem do wstydu, dlatego jadąc do miasta, zmieniano nie tylko ubranie, ale i język.

Konieczność posługiwania się w terenie obcym językiem nie jest łatwa, jeszcze trudniej, gdy są ich dwa. Ktoś mógłby powiedzieć, że można tego uniknąć, gdyż w Kraju Basków wszyscy znają hiszpański (baskijski pozostaje mniejszościowym, nawet pomimo tego, że w tej części Baskonii, na którą składa się region autonomiczny, ma on status oficjalnego języka obok hiszpańskiego). A jednak znajomość baskijskiego niewiarygodnie pomogła mi w moich badaniach, wpływając na stosunek innych do mnie i pozwalając mi na dostrzeżenie tych wymiarów miejscowej kultury, które uwidaczniają się poprzez język. Myślę, że wiele

\footnotetext{
7 Nawiązanie do popularnej piosenki zespołu Oskorri pod tytułem Euskal Herrian euskaraz, której fragment brzmi: Ez al dakizu euskara dela euskaldun egiten gaituena (tłum. „Czy nie wiesz, że mówienie po baskijsku jest tym, co czyni nas Baskami?").

${ }^{8}$ Osoba, dla której język baskijski jest językiem ojczystym (euskaldun - baskijskojęzyczny, zahar - stary).

${ }_{9}$ Dla oddania idei wypowiedzi dostosowałam tłumaczenie do polskiego rodzaju (w języku hiszpańskim dom jest rodzaju żeńskiego - la casa).
} 
nawiązanych kontaktów czy przeprowadzonych przeze mnie wywiadów było możliwych, bo moich rozmówców ujął lub zaintrygował fakt, że mówię w euskara. Oczywiście rację ma Nigel Barley, gdy dostrzega, że antropolog w terenie sprawia wrażenie, jakby przeistoczył się w językowego geniusza, bo wątek językowych trudności zwykle jest pomijany (Barley 1997: 49-50). Zdaję sobie sprawę z ograniczeń w znajomości moich „terenowych” języków, wiem też, że na moje umiejętności wpływają różne czynniki (na przykład zmęczenie, czy długi czas przebywania poza terenem).

Znajomość obu języków sprawia jednocześnie, że czuję się swobodnie w różnych kontekstach. Nie szukam gorączkowo, jak turyści, którym kiedyś pomagałam, autobusu jadącego do San Sebastián, bo wiem, że to ten, na którym widnieje napis Donostia (wiele baskijskich miejscowości ma dwie nazwy - baskijską i hiszpańską). Mieszkałam w tak wielu miasteczkach, że w większości miejsc czuję się pewnie; wiem, jak poruszać się w baskijskiej przestrzeni. W portfelu mam kilka kart bibliotecznych z różnych miejscowości (choć jakiś czas temu wprowadzono wspólny system i teraz wystarczy jedna z nich, aby korzystać z bibliotek w całym regionie). Jedna z moich współlokatorek, gdy podzieliłam się z nią refleksją, że ze wszystkich miejsc, w których mieszkałam w Hiszpanii, w Kraju Basków czuję się najbezpieczniej, roześmiała się, mówiąc: „powiedz to Hiszpanom!”.

\section{Tematy trudne}

Podczas pierwszej, autostopowej, podróży do Baskonii w 2001 r., jeden z kierowców oświadczył mi, że to niebezpieczny kraj, pełen przemocy. Mieszkanka Madrytu, z którą rozmawiałam przed laty, stwierdziła, że będąc w regionie baskijskim trzeba bardzo uważać na słowa, bo nigdy nie wiemy, z kim rozmawiamy. Sytuacja polityczna regionu baskijskiego miała istotny wpływ na charakter moich badań. Składa się na nią wiele czynników - niełatwa historia, dążenia separatystyczne, wewnętrzne podziały. A zwłaszcza przemoc, której ucieleśnieniem dla wielu jest ETA, choć warto podkreślić, że nie była to jedyna grupa stosująca terror (inną była choćby $\mathrm{GAL}^{10}$ ). Mimo że, jak zauważają niektórzy, polityka przenika każdy aspekt tutejszego życia, pytać o nią nie jest łatwo. Rozmawiam z osobami, które mają różne poglądy i doświadczenia - z bliskimi zabitych przez ETA, ale i z tymi, których krewni odsiadują wyroki za przynależność do tej organizacji. Takim spotkaniom nierzadko towarzyszą głębokie emocje, które wykraczają poza schemat klasycznego wywiadu. Ważne jest zaufanie; jeden z moich rozmówców dopiero po dłuższej znajomości przyznał, że jest więziennym strażnikiem, a przy kolejnych rozmowach żartował nawet ze swojej pracy i przytaczał mi więzienne anegdoty. Rozmawiałam także z człowiekiem, który niedawno opuścił więzienie,

${ }_{10}$ Grupos Antiterroristas de Liberación (Antyterrorystyczne Oddziały Wyzwolenia) - tajna organizacja walcząca z ETA, mająca na koncie zabójstwa, porwania i tortury (a także niewinne, „przypadkowe” ofiary), która była, jak się później okazało, wspierana przez członków hiszpańskiego rządu. 
a w jego spojrzeniu i ruchach był jeszcze rodzaj niepewności, nieobecności. Interesujące jest i to, w jaki sposób ja jestem klasyfikowana przez moich rozmówców, po „której stronie”. Historia Kraju Basków, w tym historia konfliktu hiszpańsko-baskijskiego, jest w mojej opinii wielowątkowa. W czasie rozmów przywołuję więc zwykle argumenty przeciwne do tych, na jakie wskazuje mój interlokutor. Niekiedy to wystarczy, bym w oczach osób o jednoznacznych poglądach plasowała się po stronie przeciwników (kimkolwiek byliby). Poza Krajem Basków z kolei czasem sam fakt zajmowania się tamtejszą kulturą uznawany był za dowód bycia zindoktrynowaną, przemawiającą z perspektywy grupy mniejszościowej, a zatem radykalnej (nierzadko miałam wrażenie, że głos większości uznawany jest za "neutralny" $i$ „prawdziwy"). Badania w sytuacji etnicznego, kulturowego, politycznego konfliktu mogą być związane z presją, by opowiedzieć się po którejś ze stron lub z oczekiwaniem badanych, że zajmie się jednoznaczne stanowisko. W niektórych sytuacjach badacz może też stać się obiektem manipulacji, czy też wewnętrznych rozgrywek (Kuźma 2013: 8-9).

Niektóre tematy są szczególnie trudne. Po badaniach przeprowadzonych wśród imigrantów, opowieściach o sukcesach i marzeniach, ale i o traumatycznych doświadczeniach, mylnie założyłam, że kolejne badania, dotyczące życia rodzinnego, będą emocjonalnie łatwiejsze i mniej złożone. $Z$ jednej strony w baskijskim życiu rodzinnym wyróżnić można te zjawiska, które występują i w innych miejscach (np. związane z demografią), z drugiej - te, które mocno osadzone są w lokalnym kontekście (sytuacja językowa i polityczna). Te ostatnie stanowiły dla mnie często emocjonalne wyzwanie. Mam tu na myśli choćby rozmowy z krewnymi ofiar baskijsko-hiszpańskiego konfliktu, po jego obu stronach; szczególnie zaś historie kobiet, którym po urodzeniu ukradziono dzieci ${ }^{11}$. Tym trudniejsze to dla mnie było, że sama jestem matką (syn jednej z rozmówczyń urodził się tego samego dnia, co moja córka, tylko w innym roku). Ich relacje, lektura udostępnionych mi przez nie dokumentów, sprawiały, że każdorazowo pracę kończyłam z potwornym bólem głowy; nierzadko z poczuciem, że trudno mi unieść ciężar tych opowieści ${ }^{12}$. A jednocześnie z przekonaniem, że należy o tych sprawach mówić (dbając zarazem o emocjonalny dobrostan rozmówców) (Kość-Ryżko 2013: 19). Na szczęście, dla równowagi, nie brakowało mi i bardziej pozytywnych obrazów życia rodzinnego. Bo mimo wszystko badania sprawiają mi zwykle wielką satysfakcję i radość ${ }^{13}$.

${ }^{11}$ To zjawisko miało miejsce w Hiszpanii od lat 30. do 90. XX w. Ofiarami były osoby o „niewłaściwych" poglądach politycznych, nieodpowiedniej sytuacji osobistej (na przykład brak męża) albo po prostu takie, które łatwiej było wykorzystać (biedne, słabo wykształcone). Wmawiano im, że dziecko urodziło się martwe (niekiedy dysponowano nawet "pokazowym” noworodkiem), podczas gdy w rzeczywistości trafiało do „adopcji” (często właściwszym określeniem byłoby - do sprzedaży) (Luque Delgado, Esteso Poves 2018: 169 -176).

12 Pod wpływem takich doświadczeń $\mathrm{w}$ terenie podjęłam studia podyplomowe z psychotraumatologii na Uniwersytecie Gdańskim.

${ }_{13}$ Pamiętam, jak kiedyś jeden z profesorów powiedział mi, że nie powinnam otrzymać finansowania projektu, bo za bardzo lubię to, co robię. Zdziwiło mnie to, bo w moim odczuciu nauka nie musi być związana z udręką i wyrzeczeniem. 
Zależy mi na uczciwości w rozmowie, ale też nadrzędne jest dla mnie dobro moich rozmówców, dlatego uzyskane dane anonimizuję. Jednakże niektórym zależało na tym, aby ich nazwisk użyć. Tak było w przypadku siostry człowieka zamordowanego przez ETA, nota bene dziennikarki, która powiedziała mi, że „ona chce prawdy”. Niektórzy tematów politycznych unikają (w jednym ze stowarzyszeń gastronomicznych, charakterystycznych dla tego regionu, kwestia pomijania rozmów na tematy polityczne została nawet wpisana do regulaminu). Jednocześnie współczesny Kraj Basków, w porównaniu z tym, który znałam z moich pierwszych pobytów, bardzo się zmienił, również pod względem politycznym. Pomimo tego, że autonomia, z której region cieszy się od ponad czterdziestu lat, nie wszystkich satysfakcjonuje, współczesna sytuacja jest znacznie spokojniejsza (choć do pełnego dialogu i porozumienia droga jeszcze daleka). Jest tak przede wszystkim ze względu na samorozwiązanie się ETA i ustanie zamachów; jednego z nich byłam kiedyś mimowolnym świadkiem. Pamiętam jeszcze tamto niedowierzanie, błyskawiczne pojawienie się funkcjonariuszy, strach kolegi, z którym się wówczas umówiłam. To była inna Baskonia, w której przemoc była codziennością, a niejedna matka bała się tego, jaką drogę życiową wybiorą jej dzieci. Patrzę na to również przez pryzmat własnego macierzyństwa.

\section{Badaczka i matka}

Pierwszym morzem, jakie zobaczyła moja córka, było to baskijskie. Tak polubiła jednego z mych baskijskich współlokatorów, że to jego chciała trzymać za rękę, gdy gdzieś wychodziliśmy, choć zamieniła z nim może kilka słów. On sam zauważył, że gdy specjalnie wyuczył się jakiegoś pytania po polsku, patrzyła na niego ze zdziwieniem, jakby chcąc mu uświadomić, że to niepotrzebne. Kiedyś ze słuchu nauczyła się dawnej pieśni z Nawarry. To w Baskonii przezwyciężyła lęk przed psami, choć jej psi wybraniec bardzo odbiegał od wizerunku idealnego pupila. Sierść miał szorstką i wiecznie zmierzwioną, brakowało mu kawałka ucha i języka, bez skrupułów podkradał jedzenie, a do tego cierpiał na nerwicę objawiającą się dość upiornym kaszlem. Kiedy moja córka czasem towarzyszyła mi w badaniach, miałam możliwość dotarcia do innych środowisk i zobaczenia nowych perspektyw. Jej obecność wpływała też na to, jak byłam postrzegana. Na spotkaniach dla imigrantów, podczas których razem z innymi dziećmi moja córka rysowała lub wybierała malunki na twarz, widziano we mnie nie tylko badaczkę, ale i matkę. Sądzę, że to ułatwiało akceptację mnie jako kogoś nie tak obcego, odmiennego; pozwalało zobaczyć we mnie nie tylko zewnętrznego obserwatora, który z daleka patrzy i ocenia. Moja obecność w tego typu miejscach stawała się bardziej naturalna, a tym samym zmniejszała stopień zmian zachowań wywołanych moim przybyciem. W podobny sposób działała obecność członków mojej rodziny podczas badań baskijskiego życia rodzinnego. W czasie świąt w Algorcie, na które przyjechałam z moimi bliskimi, mogłam w bardziej bezpośredni sposób doświadczyć wydarzeń zorganizowanych z myślą o rodzicach i dzieciach. Gdy moja córka 
brała udział w zorganizowanych zabawach, jedna z poznanych rozmówczyń podeszła do mnie z własnej inicjatywy, chciała bowiem przekazać mi informację, że dziecko może spróbować tradycyjnych sportów. Niebawem okazało się, że był to początek jednej z bardzo wartościowych rozmów tego popołudnia.

Nie bez znaczenia jest także emocjonalne wsparcie, bo przecież antropolog $\mathrm{w}$ terenie bywa samotny a czasem trudno mu nawiązać rozmowę z wybranym "tubylcem” (zwłaszcza gdy ten, jak w czasie uroczystości, otoczony jest krewnymi i przyjaciółmi). W takich spostrzeżeniach nie jestem odosobniona - Katarzyna Kalinowska wskazywała na to, że podczas badań na turnusie rehabilitacyjnym znacznie łatwiej było jej włączyć się w „kuracyjny styl życia” i nawiązać kontakt z badanymi, gdy przyjechała z mężem, niż gdy prowadziła badania sama (Kalinowska 2015: 122), zaś Katarzyna Kość-Ryżko doświadczyła zmiany stosunku do niej badanych w czasie, gdy była w widocznej ciąży oraz kiedy podczas badań towarzyszyli jej mąż i dziecko (Kość-Ryżko 2013: 31-32).

Bycie $\mathrm{w}$ terenie $\mathrm{z}$ dzieckiem ułatwia rozmowy i obserwacje innych dzieci, a także stosunku do dzieci w danej kulturze. Bez wątpienia bycie matką odcisnęło też ślad na tym, jaką stałam się badaczką, jakie tematy przyciągnęły moją uwagę i do jakich spraw mnie dopuszczano. To, że i ja miałam dziecko, sprawiało, iż moje rozmówczynie otwarcie dzieliły się ze mną macierzyńskimi przeżyciami, nierzadko bardzo intymnymi, czasem oczekując wzajemności, co nie zawsze było dla mnie łatwe, a zarazem pozwalało mi lepiej zrozumieć drugą stronę (poprzez znalezienie się w roli osoby pytanej). Do trudnych należały też sytuacje, w których byłam świadkiem praktyk wychowawczych sprzecznych z takim podejściem do dziecka, które jest mi bliskie. Obserwacja „mojego” dziecka w „moim” terenie stanowiła też dla mnie cenny element autoetnografii. Jej składnikiem były choćby spostrzeżenia córki w odniesieniu do mnie - do tego, jak ona widzi mnie podczas pracy. Dla mnie takie doświadczenia były zarazem częścią konfrontacji ze mną samą, z moimi dążeniami, frustracjami, ograniczeniami; tym bardziej, że przez pierwszych kilka lat prowadzenia badań w Kraju Basków nie byłam matką. Trudno przecenić takie doświadczenia.

Nie jest niczym nowym przyznanie, że nasz wiek, płeć, pochodzenie, a także to, czy badania prowadzimy w towarzystwie rodziny, czy samodzielnie, $\mathrm{w}$ istotny sposób wpływają na uzyskiwane dane. Coraz częściej piszą o tym antropolodzy i antropolożki, matki, a niekiedy też ojcowie. Tym cenniejsze wydaje się więc dążenie do tego, aby w jak największy sposób poszerzać te doświadczenia prowadząc badania samodzielnie lub w towarzystwie rodziny, wracając do tego samego terenu po latach, ale już w nowych rolach - co dać nam może kolejne pole do szeregu interpretacji ${ }^{14}$.

${ }^{14}$ Cenna jest dla mnie triangulacja, w jak najszerszym wymiarze: źródeł, metod, próba łączenia wielu ról i perspektyw w terenie, indywidualne i elastyczne podejście do przedmiotu badań. Metodologiczny pluralizm jednak budzi mieszane uczucia i jest, jak zauważył Antoni Sułek, "przez niechętnych zwany eklektyzmem" (Sułek 1990: 7). W mojej opinii różnorodność form i perspektyw stanowi zaletę, gdyż "nie ma lepszych i gorszych metod badawczych - są po prostu różne, jak różne są temperamenty i wizje świata poszczególnych badaczy” (Kacperczyk 2014: 68). 
Innym elementem, który - jak się wskazuje - ma często znaczenie podczas badań, jest wygląd fizyczny badacza (Hammersley, Atkinson 2000: 101). Bez wątpienia również jego płeć (zagadnienie doświadczeń tak w terenie, jak i w świecie akademickim w relacji z płcią to temat na odrębny artykuł). Mój wygląd zwykle pomagał w pozytywnym odbiorze mojej osoby, wzbudzał zaufanie i życzliwe zainteresowanie. Wpisuję się w pozytywnie waloryzowany w Hiszpanii typ urody (jestem biała, mam stosunkowo jasne włosy, niebieskie oczy) (Kunz 2002: 172). Mam wrażenie, że moja powierzchowność nie jest też onieśmielająca, moi rozmówcy zwykle dziwią się, poznając mój wiek czy zawód. Któregoś dnia na ulicy podeszła do mnie starsza pani, podając mi swój telefon komórkowy i prosząc, bym zadzwoniła do jej męża, bo ona nie wzięła okularów i nie jest w stanie wybrać jego numeru. Gdy kiedyś zapomniałam biletu, pracownik stacji kolejowej z uśmiechem zareagował na moje wyjaśnienie o przyczynie zamyślenia. Czuję, że te reakcje byłyby inne, gdybym nosiła muzułmańską zasłonę lub miała ciemniejszy kolor skóry. Widzę różnice w spojrzeniach przechodniów, gdy idę z koleżanką z Algierii. "Jesteś biała, więc nie doświadczyłaś dyskryminacji” - słusznie zauważył jeden z moich przyjaciół. To nie znaczy, że nie wyglądam egzotycznie. Na pewno czasem wolałabym mieć mniej cudzoziemski wygląd, mniej przyciągać wzrok, choć w Kraju Basków nikt ostentacyjnie nam się nie będzie przyglądał i tego, że jesteśmy w centrum uwagi, możemy nie spostrzec. Doświadczyłam tego podczas święta w jednej z nawarskich miejscowości, gdy myślałam, że nikt z obecnych nie dostrzegł mojej obecności, podczas gdy mój towarzysz powiedział mi później, że faktycznie byłam na ustach niemal wszystkich.

\section{Zażyłość i zaangażowanie}

„Przyjedź do domu”. „Przenocuj w domu”. „Tu masz dom” - słyszę. W mieszkaniach moich rozmówców i przyjaciół napotykam na ślady mojej wcześniejszej bytności, doznaję drobnych, acz głęboko życzliwych gestów ze strony ludzi, którzy słyną z powściągliwości. Czasem, by dostrzec ich wagę, potrzeba wyczulenia na tutejszą wrażliwość, na charakter wyrażanych uczuć.

W Kraju Basków mam wielu znajomych i kilkoro przyjaciół. Ci najbliżsi od lat odpowiadają cierpliwie na moje pytania, wprowadzają mnie do swoich środowisk, pomagają. Spotykaliśmy się na różnych etapach naszych biografii, dzieliliśmy rozmaite chwile, sporo o sobie wiemy. Czy to wciąż rozmówcy i antropologiczni „odźwierni”? W baskijskiej stolicy kimś takim jest dla mnie moja przyjaciółka, dawna fryzjerka i wspaniała gawędziarka. W Tolosie mieszka inny przyjaciel i niezastąpiony tłumacz tutejszych realiów. Są też Polki - jedna to moja koleżanka z lekcji języka baskijskiego, dziś przyjaźnią się nasze córki, druga była moją studentką i dzięki niej Zarautz stało się moim „drugim domem". Ważną dla mnie osobą jest także Baskijka, która pracowała w Polsce jako lektorka i której spojrzenie na miejscową kulturę bardzo cenię; albo 
miłośnik poezji, z którym po raz pierwszy wspięłam się na Anboto - mityczną siedzibę tutejszej bogini ${ }^{15}$.

Kwestia zaangażowania obecna jest w antropologicznych dyskusjach od lat (choć wciąż bywa rozmaicie definiowana). Coraz częściej można spotkać się z opinią, że każda antropologia jest lub powinna być zaangażowana (Barański 2010: 35), czy że „antropologia, która nie złamie ci serca, nie powinna być kontynuowana" (Kacperczyk 2014: 65). Bliska mi jest taka perspektywa. Wierzę w ważność zanurzenia się w badanej rzeczywistości, uczestniczenia w codziennych praktykach, dzieleniu codzienności z badanymi, ale i podejmowaniu działania, gdy to konieczne. Związane jest z tym zaangażowanie emocjonalne, na wielu poziomach. Pytania o etykę prowadzenia badań, w tym te związane z „zażyłością" z badanymi czy z informacjami uzyskanymi w ramach obecności niejawnej, są dla mnie codziennością w terenie. Gdy osiągnie się bliskość, nagle największym problemem staje się to, by zaufania nie nadużyć. Niełatwo jest wyznaczyć granicę pomiędzy przyjaźnią i badaniem (Nowicka 2016: 40-53). Ocena tego, czy bliskie relacje w terenie są etyczne i możliwe, a także, jak zachować dystans przy długotrwałym kontakcie, i czy istnieje alternatywa dla zażyłości, pozostają przedmiotem debat wielu badaczy, wciąż nierozwiązanym problemem (Oliwińska 2015: 19-24). Według niektórych, można prowadzić długotrwałe badania, zachowując dystans i profesjonalizm, którego dowodem będzie zerwanie kontaktu po wyjeździe z terenu. Jednak dla mnie wywiad to spotkanie, dialog, relacja wykraczająca poza jednorazowe zdobycie informacji. Jestem też zwolenniczką jawności, jednak zauważam, że choć moi rozmówcy znają powód mojego przyjazdu i temat moich badań (i często aktywnie pomagają mi w znajdowaniu kolejnych interlokutorów, czy też podsuwają interesujące wątki), to z biegiem czasu przestaję być dla nich „antropolożką z Polski”. Codzienne rozmowy przy kolacji z jedną z moich współlokatorek, z każdym wieczorem stawały się coraz bardziej osobiste. Ich temat wielokrotnie wpisywał się w zakres moich badawczych problemów, lecz ze względu na kontekst sytuacji, który bynajmniej nie sprzyjał przypomnieniu rozmówczyni o moich badaniach i moje poczucie, że dane treści przeznaczone były dla uszu przyjaciółki, a nie badaczki, sprawiły, że nie wykorzystałabym nigdy tych informacji, choć były cenne. Przyjaciel opowiadający mi o rodzinnych konfliktach i sercowych rozterkach nie jest dla mnie „informatorem”, choć jego spostrzeżenia dotyczą ważnych elementów tutejszej uczuciowości. Podobnie ten, który opowiada o chorobie matki umieszczonej w domu opieki. Sądzę, że i dla moich rozmówców przebywanie ze mną może być czasem zastanawiające. Spotykałam się niekiedy z pytaniami: „czy my jesteśmy dla ciebie takim dzikim plemieniem?" albo „czy to znaczy, że teraz, podczas imprezy, też nas badasz?”.

Kiedyś mieszkałam u jednego z przyjaciół. Gdy wyjeżdżałam, mój gospodarz był nieobecny, dlatego klucz przekazałam jego bratu, który stwierdził wówczas, że nigdy jeszcze nie był w opuszczanym właśnie przeze mnie domu. Nie było

${ }_{15}$ Naczelna postać w baskijskiej mitologii to żeńskie bóstwo - Mari. Jej siedzibą, według wierzeń, były baskijskie góry (Mirgos: 2010). 
to bynajmniej oznaką złych relacji pomiędzy rodzeństwem, dla baskijskiej kultury charakterystyczne jest to, że przestrzeń domowa rzadko bywa miejscem spotkań towarzyskich, nawet bliskich sobie ludzi: przedłużeniem „swojskiej” przestrzeni jest ulica, jak zauważył Toni Strubell (2005: 39). Tym bardziej doceniam zaufanie, jakim obdarzają mnie ci z moich rozmówców, którzy zapraszają mnie do swych domów.

Mieszkanie z członkami badanej grupy utrudnia zdystansowanie się i odpoczynek, gdy czujemy się znużeni terenem. Jednocześnie fakt, że z niektórymi z moich rozmówców współpracuję od wielu lat, nocuję w ich domach, obserwuję, jak rosną ich dzieci, pozwala mi poszerzyć uzyskany materiał i zweryfikować to, co deklarowane. Czasem też wywołuje pewne niezręczności, jak choćby w obliczu szczerego komentarza wypowiedzianego przez dziecko, rzucającego nieco inne światło na obraz zarysowany przez rodzica. Długotrwałe relacje w terenie sprawiały, że byłam powierniczką i świadkiem narodzin i śmierci, rozstań, starzenia się, depresji, czy terapii. Dzieliłam codzienne praktyki i przestrzenie. Osiągając to, co w naszych badaniach uznaje się za tak cenne, a być może najcenniejsze bliskość w codzienności z miejscowymi, dostęp do tego, co dla nich istotne, przekonałam się, że taka wiedza i doświadczenie łączą się przede wszystkim z poczuciem odpowiedzialności. Zwykle te najcenniejsze rozmowy miały miejsce na górskim szlaku lub przy kuchennym stole. Czasem inicjowałam wywiad rejestrowany za pomocą dyktafonu, ale mimo naszej zażyłości, była to forma bardzo stresująca dla moich rozmówców. Zresztą tak zdarzało się i w przy padku innych rozmów, nie tylko z długoletnimi „współpracownikami” (może poza osobami publicznymi, przyzwyczajonymi do takich praktyk). Nierzadko, po zakończeniu sformalizowanego wywiadu, zaczynała się zupełnie inna rozmowa, a w niej pojawiały się wątki podważające wcześniejsze wypowiedzi i deklaracje. Przykładem takiej sytuacji była dla mnie rozmowa z pracującym na jednym z kempingów Senegalczykiem, która zmienila charakter, gdy zamknęłam zeszyt z zapisanymi pytaniami i wątkami, jakie chciałam poruszyć. Mój rozmówca wcześniej wielokrotnie zapewniał o pozytywnych relacjach z miejscowymi, a także o tym, że nigdy w Baskonii nie doświadczył dyskryminacji. Gdy jednak schowałam notatnik, zaczął opowiadać między innymi o tym, że miejscowe społeczeństwo postrzega go jako mało inteligentnego, ze względu na jego kolor skóry.

Praca z naszymi własnymi emocjami, bliskość w terenie, moralny obowiązek działania, nie są już dziś może tematem tabu, a jednak mam poczucie, że wciąż $\mathrm{w}$ niewielkim stopniu przygotowujemy studentów do takich przeżyć. Podkreślamy ważność badań terenowych, znaczenie ich intensywności. Brakuje jednak narzędzi, które wskazywałyby, w jaki sposób należałoby radzić sobie z naszymi emocjami. Czasem rolę doradcy w tym względzie pełni kolega czy koleżanka, inny badacz czy badaczka, choć są to raczej porady nieformalne. Tymczasem sprawa jest ważna, bo jednak wielu z nas wraca z terenu nie tylko fizycznie, ale i emocjonalnie wyczerpanych. Stąd być może rodzi się konieczność wypracowania swoistego „zbioru zasad bezpieczeństwa i higieny pracy w terenie”, co trafnie zauważyła Iwona A. Oliwińska (2015: 24-26). 
Również i ja miałam czasem poczucie jałowości badań w konfrontacji z cierpieniem; rosło we mnie przekonanie, że antropolog nie może być obojętnym w obliczu zła (Brocki 2013: 67-68). Uważam, że antropologiczne badania powinny obejmować całość ludzkiego doświadczenia, którego elementem jest też ból, choć kwestia tego, w jaki sposób "oddać głos tym, którzy cierpią" pozostaje dyskusyjna (Herzfeld 2004: 303-329). Między innymi takie doświadczenia sprawiły, że w coraz większym stopniu wierzę w antropologię „pisaną sercem”, zrozumiałą dla szerokiego grona czytelników, wzbudzającą emocje, które prowokują do tego, „by coś zmienić" (Kępa 2014: 82-84). Antropologia to dla mnie w znacznej mierze rodzaj wrażliwości oraz pewna postawa moralna (Buchowski 2013: 503).

\section{Na rozdrożu}

Ostatnio (czyli w 2019 r.), wchodząc do klatki schodowej mojego "terenowego" mieszkania, przez chwilę pomyślałam, że to mógłby być mój dom. Patrząc przez okno na zapalające się światła w baserriak w pobliskich górach, odczuwałam dystans dzielący mnie od mojego życia w Polsce. Nieobce jest mi poczucie rozdarcia pomiędzy światami i towarzyszący temu wachlarz emocji od złości do wdzięczności. W Kraju Basków jestem zwykle spokojniejsza, na co wpływ ma tutejsze podejście do codziennych spraw i ludzkich słabości. A jednak są też momenty, gdy czuję się w „moim terenie” obca i samotna; gdy odczuwam różnice w moich doświadczeniach i sposobach patrzenia na świat; kiedy jestem zmęczona posługiwaniem się innymi językami, które zmieniam w zależności od rozmówcy, gdy znużona mylę językowe formy i nie mogę znaleźć właściwego synonimu; wreszcie gdy mam poczucie, że cały czas jestem „,w pracy”. "Jak to?" - dziwi się jeden z moich baskijskich przyjaciół - „Przecież Twoja relacja z Krajem Basków jest tak bliska". Może dlatego przez długi czas miałam też trudności z połączeniem dwóch egzystencji - życia w Polsce, wśród rodziny i przyjaciół oraz życia w Baskonii, z ludźmi, którzy są również częścią mojej tamtejszej codzienności. Opuszczanie każdego z tych światów wiązało się dla mnie z poczuciem straty i rozdarcia, do czasu, kiedy wreszcie dostrzegłam w tym doświadczeniu istotną wartość i zaakceptowałam moją transnarodową tożsamość.

Inna kwestia dotyczy tego, co dzieje się w terenie i co wydarza się po powrocie z niego. Nie chodzi mi tylko o trudność emocjonalnego powrotu, gdy ciałem jest się w jednym miejscu a myślami wciąż w terenie (zwykle przez kilka dni po powrocie do Polski zdaje mi się, że ludzie na ulicach rozmawiają po baskijsku), ale też o pewną nieprzystawalność rzeczywistości akademickiej i terenowej. Któregoś dnia prosto z madryckiego międzynarodowego kongresu antropologicznego jechałam na badania terenowe do Baskonii. Jedno z wygłoszonych tam wystąpień dotyczyło hodowli pomidorów w regionie baskijskim z perspektywy antropologii pokrewieństwa. Kiedy wreszcie dotarłam do Baskonii, odebrał mnie ojciec jednego z przyjaciól, zapalony hodowca pomidorów, który niemal całe życie spędził w swym rodzinnym gospodarstwie. Wzbogacona o wiedzę 
zdobytą na kongresie, a dotyczącą tego, że niemal wszystkie uprawiane w Kraju Basków pomidory pochodzą z jednej konkretnej odmiany, o nazwie Jack, zapytałam mojego rozmówcę o to, czy i w jego hodowli one dominują. Spojrzał na mnie, trochę zdziwiony, a po chwili odpowiedział, że on hoduje „te pomidory, co zawsze”. Dostrzegając czasem odmienność, by nie powiedzieć przepaść, pomiędzy tym, co spotyka nas w terenie i tym, co przeżywamy w uniwersyteckich salach, zastanawiam się nad tym, co to znaczy być antropologiem i jaki jest cel antropologicznych badań ${ }^{16}$. W chwili tamtej rozmowy o pomidorach poczułam, po raz kolejny, że jest mi najbliżej do „zwyczajnych” ludzi. Nie pociągają mnie zawiłe teksty, niezrozumiałe dla wielu z naszych rozmówców, potwierdzające przede wszystkim naszą erudycję. One w istocie rzadko zmieniają świat tych ludzi, których badamy, a niekiedy tworzą granicę pomiędzy „wiedzącym lepiej” autorem i podrzędnym „ciemnym” czytelnikiem (Kacperczyk 2014: 50). Stąd propozycje dotyczące innych sposobów prezentowania wyników badań i zerwania z „językiem władzy” (Baer 2014: 139-144, 160-167). Dla mnie największym osiągnięciem jest rozmowa, która sprawia, iż rozmówca cieszy się tym, że w niej mógł uczestniczyć. Nie tak dawno właśnie tak się poczułam, gdy po opisaniu losów jednego z hiszpańskich „ukradzionych dzieci”, moja rozmówczyni ze wzruszeniem dziękowała mi za zajęcie się jej historią. Badania dotykające tego tematu były dla mnie pod względem emocjonalnym jednymi z trudniejszych, ale jednocześnie i jednymi z ważniejszych.

I patrzę na te dojrzałe pomidory wyhodowane przez ojca mojego przyjaciela, które leżą przede mną na stole, roztaczając wokół intensywny zapach. „W naszej, baskijskiej kuchni pomidory są bardzo cenione, zwłaszcza te z baserrii” - nadmienia moja współlokatorka, dodając: „od razu czuć różnicę ze sklepowymi”. Wówczas przypominam sobie, jak ich hodowca, siedemdziesiesięciolatek, o twarzy ogorzałej od słońca, doskonałej kondycji, której pozazdrościć mógłby mu niejeden z moich rówieśników, w skupieniu wybierał je dla mnie.

„Dla Kasi te najlepsze” - słyszałam, jak szeptał jego syn.

\section{Literatura}

Baer, M. (2014). Między nauką a aktywizmem. O polityczności, płci i antropologii. Wrocław:

Wydział Nauk Historycznych i Pedagogicznych Uniwersytetu Wrocławskiego.

Barański, J. (2010). Antropolog badaczem czy działaczem? W: F. Wróblewski, E. Sochacki, J. Steblik, Antropologia zaangażowana (?) (s. 29-36). Kraków: Wydawnictwo Uniwersytetu Jagiellońskiego.

Barley. N. (1997). Niewinny antropolog. Notatki z glinianej chatki. Warszawa: Prószyński i S-ka. Benedyktowicz, Z. (2016). Elementarz tożsamości. Antropologia wspótczesności - antropologia kontekstowa. Wołowiec: Wydawnictwo Czarne.

${ }_{16}$ Dziś sporo jest głosów poszukujących antropologii „poza akademią” (Sikora 2016, Hummel 2017: 310-318). Obecne są też opinie krytyczne wobec instytucji naukowych czy wskazujące na tworzenie się, jak zauważyła Barbara Fatyga, "naukowych dworów” i "naukowych mafii” (2015: 256). 
Brocki, M. (2013). Antropologia społeczna i kulturowa w przestrzeni publicznej. Problemy, dylematy, kontrowersje. Kraków: Wydawnictwo Uniwersytetu Jagiellońskiego.

Buchowski, M. (2017). Antropologia polska: genealogie, trajektorie i etyczne powinności. Lud, 101, 485-505.

Ellis, C. (2014). The etnographic I. A methodological novel about autoetnography. Oxford: Altamira.

Etxeberria, H. (2012). Euskal sukaldaritzaz. Sobre la cocina vasca. On Basque Cuisine, Donostia/ San Sebastián: Etxepare Euskal Institutua

Fatyga, B. (2015). Praktyki badawcze na skrzyżowaniu równoległych dyskursów. Wstępny przegląd zagadnień do analizy kulturalnych dyskursów o kulturze. W: B. Fatyga (red.), Praktyki badawcze (s. 254- 267). Warszawa: Instytut Stosowanych Nauk Społecznych UW.

Hammersley, M., Atkinson, P. (2000). Metody badań terenowych. Poznań: Wydawnictwo Zysk i S-ka.

Herzfeld, M. (2004). Antropologia. Praktykowanie teorii w kulturze i społeczeństwie. Kraków: Wydawnictwo Uniwersytetu Jagiellońskiego.

Hummel, A. (2017). Szkic o antropologii aktywistycznej. Badanie nowo-wiejskich inicjatyw w Katalonii. Lud, 101, 305-332.

Kacperczyk, A. (2014). Autoetnografia - technika, metoda, nowy paradygmat? O metodologicznym statusie autoetnografii. Przegląd Socjologii Jakościowej, 10/3, 32-75.

Kalinowska, K. (2015). Podryw kontrolowany. Rola pracy zespołowej i relacji miedzy badaczami w terenowych badaniach emocji. W: B. Fatyga (red.), Praktyki badawcze (s. 113-129). Warszawa : Instytut Stosowanych Nauk Społecznych UW.

Kępa, E. (2014). Autoetnografia nie wzięła się znikąd - rozważania o ciągłości i zmianie. Parezja, 1, 79-89.

Kość-Ryżko, K.B. (2013). Etnolog w labiryncie znaczeń kulturowych. Psychologiczne wyzwania badań terenowych. W: I. Kuźma (red.), Tematy trudne. Sytuacje badawcze (s. 15-47). Łódź: Wydawnictwo Uniwersytetu Łódzkiego.

Kubica, G. (2007). Wstęp. W: Bronisław Malinowski. Dziennik w ścistym znaczeniu tego wyrazu, Kraków: Wydawnictwo Literackie.

Kunz, M. (2002). La Polonia de Getafe: Algún día, cuando pueda llevarte a Varsovia de Lorenzo Silva. W: I. Andres-Suárez, M. Kunz, I. D’Ores. La inmigración en la literatura española contemporánea (s. 165-184). Madrid: Editorial Verbum.

Kuźma, I.B. (2013). Tematy trudne - pola minowe - tabu w badaniu naukowym. Słowo wstępne. W: I. Kuźma (red.), Tematy trudne. Sytuacje badawcze (s. 7-11). Łódź: Wydawnictwo Uniwersytetu Łódzkiego.

Luque Delgado, S., Esteso Poves, M.J. (2018). El robo de bebés desde una perspectiva de género. Nuestra historia, 5, 169-176.

Majbroda, K. (2013). Drogi wiedzy w antropologii społeczno-kulturowej po zwrocie ku sensoryczności i niedyskursywnemu doświadczaniu rzeczywistości. Lud, 97, 17-38.

Mirgos, K. (2010). Mit Mari. Jego źródła i miejsce w kulturze Basków. Wrocław: Polskie Towarzystwo Ludoznawcze.

Nowicka, E. (2016). Antropolog wobec innych i wobec siebie. Niektóre problemy etyczne uprawiania antropologii. Przegląd Socjologii Jakościowej, 12, 3, 40-53.

Oliwińska, I.A. (2015). Domorosły majsterkowicz? Szkic o statusie, rolach i dylematach badacza terenowego. W: B. Fatyga (red.), Praktyki badawcze (s. 17-26). Warszawa: Instytut Stosowanych Nauk Społecznych UW.

Sikora, M. (2016). W kierunku praktycznego wymiaru antropologii. Studia Etnologiczne i Antropologiczne, 16, 85-100. 
Strubell, T. (2005). Un catala entre Bascos. Barcelona: La Campana.

Sułek, A. (1990). W terenie, w archiwum $i$ w laboratorium. Studia nad warsztatem socjologa.

Warszawa: Uniwersytet Warszawski, Instytut Socjologii.

Szyszkowska, M. (1993). Filozofia polityki. Filozofia prawa. Filozofia twórczości. Warszawa: Oficyna Naukowa.

Young, M.W. (2008). Bronisław Malinowski. Odyseja antropologa 1884-1920. Warszawa: Wydawnictwo Książkowe Twój Styl.

Zuazo, K. (2010). El euskera y sus dialectos. Irun: Alberdania.

\section{SUMMARY}

Tomatoes are the same as usual. Reflections on fieldwork in the Basque Country

This article focuses on personal experience of fieldwork in the Basque Country. The author reflects on the linguistic and political dimensions of her research, on the relationship between the researcher and research participants, and on the emotional challenges of ethnographic fieldwork, with particular focus on the impact of motherhood on such research. Emphasizing the importance of autoethnography, the author also points out a variety of approaches to the research process and ways of presenting research results.

Keywords: Basque Country, Euskara - Basque language, autoethnography, fieldwork 